\title{
INTERNAL QUALITY ASSURANCE IMPLEMENTATION MODEL AS ORGANIZATIONAL QUALITY ASSURANCE IMPLEMENTATION
}

\author{
Sunarni \\ Department of Educational Management \\ State University of Malang, Indonesia \\ jengnarni@yahoo.co.id
}

\author{
M. Huda A. Y \\ Department of Educational Management \\ State University of Malang, Indonesia \\ muhammad.huda.fip@um.ac.id
}

\begin{abstract}
The purposes of research are to: (1) find out internal quality assurance implementation model; and (2) offer internal quality assurance model as effective organizational quality assurance implementation at kindergarten. This research uses qualitative approach with multi-cases design. Data collection techniques used are interview, documentation, and observation. Subjects of research are TKN I Pembina Kota Malang, TK Berita Hidup, and TK Assalam. Data analysis of each cases uses Miles and Huberman interactive and cross case analysis model. The results are: (1) quality assurance model in those 3 kindergartens is categorized as good, average and poor, (2) some kindergartens are organized well in job describtion for preparing external quality assurance document and have sufficient human resources. But there is also kindergarten which is not good in preparing job describtion does not have sufficient human resources, (3) all research subjects do not have specific organization which handles internal quality assurance; and (4) district educational department, head of charity and principal have tried to guide, motivate, and lead the activity of internal and external quality assurance of the schools.
\end{abstract}

Keywods: quality, organizational quality assurance

\section{INTRODUCTION}

Kindergarten is an educational institution which belongs to early age of formal education and conducted before primary school. Education in kindergarten aims at leading children to be selfreliance person and introducing knowledge since early age. Knowledge to be introduced are religion, social, cognitive and motoric, physical (golden age). There are 3 (three) important reasons for education in kindergarten: (1) as a basic phase for children development, (2) learning and developing is a continuous process, and (3) motivating parents to care more to education of their children. Bartol et al (2002) stated that management is "the process of achieving organizational goals by engaging in the four major functions of planning, organizing, leading, and controlling". While Massie (1964) stated that "management is defined as the process by which a cooperative group directs actions toward common goals. This process involves techniques by which a distinguishable group of people (managers) coordinate activities of other people; managers seldom actually perform the activities themselves. This process consists of certain basic functions which provide an analytical approach for studying management".

Kurniadin and Machali (2012) stated that educational management basically is tools which are needed in achieving educational purposes consisting of planning, organizing, movement and monitoring related to educational sector. Educational management substances consist of: curriculum, human resources, financial, students, instruments and public relation. Concept of Total Quality Management (TQM) has been proposed by Dr. Edwards Deming in 1940, but it is used in 1985 by taking over of American workers principles in Japanese Industry. Key elements needed to the successfulness of TQM are: faith, training, teamwork, leadership, recognition and communication. Pandhi (2000) stated that for successfulness of TQM, an organization depends on 8 key factors of TQM: (1) ethics; (2) integrity; (3) trust; (4) training; (5) teamwork; (6) leadership; (7) recognition; and (8) communication.

Legal basics of quality assurance in kindergarten are decision of national education minister No. 632009 about Educational Quality Assurance System and No. 582009 about Standard of Early Age Education. Each kindergarten must be accredited, in which it is conducted by external sector. There are 8 standards that must be prepared in accreditation: standard of development achievement level, content, process, educator and educational staff, instruments, management, financial and educational evaluation. Wahyuni in her research (2015) found out: first, strategical value of service is determined by 5 dimensions: characteristic, faith, comfort, hope and achievable. Second, strategies conducted are: (1) external strategies, it is creating institution identity so that people recognize it; (2) internal strategy, it is developing service quality through the development of teacher character, instrument providing and educative game, and conducive environment; and (3) interactive strategy, it is developing mutual relationship with parents and community surroundings through service providing of integrated PAUD (Children Treatment Park, Game Group, and Kindergarten), creating school committee, and parents social group, and maximize parents as media for institution promotion. Third, parents role as: (1) relationship agent; and (2) controlling agent.

To defend strategical values of service in an organization, we need organizational internal quality assurance to have people get faith to our institution. There must be serious preparation for school to be exist. If a school has good accreditation score, then people will be interested in the school and they will not feel objected in paying fee for their children, and vice versa. Therefore, consumer's willingness and satisfaction must be considered. Educational institution/school has to conduct quality assurance, and have quality evaluation standard. A school prepares report material in such a long time. There are 
differences of accreditation proposal in kindergarten. After 2015, an institution which accredited kindergarten is National Accreditation Organization for Non Formal Education (BAN-PNF). Regulation and policy of Early Age Education (PAUD) is based on Undang-Undang Dasar 1945, 28c, verse I, which is described more in national regulation, government regulation, president regulation, and minister regulation. Then it is described more in institution of central PM PAUD (Gutama and Herarti, 2015). It is stated in Figure 1. Figure 1 Regulation and Quality Assurance Policy of PAUD. Sonhadji (2012:195) stated,"Quality assurance basically is an implementation of government policy, as an effort to manage effective and qualified organization. Education needs quality evaluation standard. Quality standard is integration of good or service characteristics, including established management system and consumer's need.

\section{METHODS}

This research uses qualitative approach with multi-cases study design. Researcher uses qualitative approach because we want to figure out and find out internal quality assurance model as implementation of organizational quality assurance in kindergarten in Malang. This research uses multi-cases study design because we have more than 2 (two) cases in 3 (three) kindergartens. In qualitative approach, we use interview, document analysis and observation as method of data collection. Researcher is a key instrument as a collector of research data.

Data analysis of each cases uses Miles and Huberman models (1992), they are interactive and cross-case data analysis model. Data credibility test uses: a) triangulation, it is source and technique triangulation and b) member checks. Subjects of research are kindergarten which have public background, TK Negeri Pembina Kota Malang in Jalan Cibogo Penanggungan, Malang, Islamic background, TK Assalaam Arjosari, in Jalan Teluk Pelabuhan Ratu Kompleks Masjid Assalaam Arjosari, Malang, and Christen background kindergarten, TK Berita Hidup at Jalan Rawisari 33 Malang. These three kindergartens are categorized as good (Accredited A), average (Accredited B), and poor (Accredited C).

\section{RESULTS AND DISCUSSION}

There is special institution which conducted accreditation in kindergarten, it is BAN-PNF. In this term, kindergarten sends proposal and fill in some forms. Then these forms are delivered Department of Education, and sent to provincial level (as consultant). If the document is fixed and clear, it is sent back to BAN-PNF. If the document is not fixed and clear, it will be sent back to disctrict educational department and school must fix it. If the document has already fixed, it is then sent to Province Educational Department, then to BAN-PNF. After this process has completed, assessor will come to school to cross-check the document. Learning Group - TK Pembina Negeri I Kota Malang is led by Dra. Nurhayati, M.Pd, a public servant who lead 17 subordinates. This Learning Group Kindergarten got national first winner of competition in Widya Pakarti Nugraha aspect (competition of 4 characters of 18 characters). This kindergarten is proposed as guiding kindergarten for kindergartens in Indonesia. People in Kota Malang tend to send their children to this kindergarten. They said that it has good quality, accredited A, good facilities, good teacher and affordable school fee.

Composing of accreditation report has 8 standards, and it has different technique with the previous accreditation system. It is now the task of BAN-PNF who conduct accreditation. Today, BANPNF accredite Learning Group of 3-4 years old children, kindergarten of 4-6 years old children, Children Picking Up Organization, Similar Type of PAUD, Pos PAUD. Before composing accreditation document, there is some preparation that must be conducted by the school. BAN-PNF delivers letter to East Java Province, then it is sent to Educational Department of Kota Malang. This department conducts accreditation preparation workshop, in which each subdistricts send 20 kindergarten, so total kindergarten who join workshop is 100 .

The ready document then is sent to district educational department, to provincial educational department and to Jakarta (BAN-PNF). The difference is also related to filling in of short material which is completed by physical proof (2 last years). In TK Pembina Negeri 1, there are coordinators who conduct daily tasks. Each teachers has their own tasks in composing accreditation report. Preparation of accreditation report composing in TK Pembina lasts about 1 month, helped by teachers and Field Practical University Students. There is a meeting with members to discuss about any urgent materials. The composing of accreditation material is conducted in relatively fast manner because all forms have been well documented. School conducts managerial functions such as curriculum, financial, human resources, facilities, students and public relation under guidance, motivation and control of principal. Figure 1shows the phase of quality assurance in TKN 1 Pembina.

TK Berita Hidup is begun with charity organizational certificate 2008 at J1. Rawisari Mulyorejo Kota Malang, and the year of school development is in 1991. This kindergarten consists of 2 classrooms. The headmastress of this school is Mrs. Teresia Sutari, T.Ht of 63 years of age. She actually has been retired but the foundation management asked her to stay to help increasing shool which is near with bunnishment rubbish from Malang city and student's parents from lower level economic. For operational finance, this school does not take from parents because their monthly educational fee sometimes is not fully paid. Much financial sector of this school is helped by "BOSDA" and Korea Selatan country, Christian Foundation that is centerd on Solo, UNKRIT, and US in the first of their existence. An expensive educational fee of TK Berita Hidup is similarly compared with other kindergarten. But this fee is too higher from parents who mostly work as picking rubbish worker. That fee is $\mathrm{Rp} 30.000,00 /$ month and basic contribution for registering in that school is Rp 300.000,00. That includes uniform and school facilities, but this school 
gets financial sponsorship from some outside sectors. Because of this condition, the parents still hope to get the help continuously. On the other hand, financial volunteer has limited that fee in order to that kindergarten be autonomous educational organization. The helping is also for school facilities and delivery process is done by volunteer itself.

Quality Assurance Implementation Model in TKN Pembina

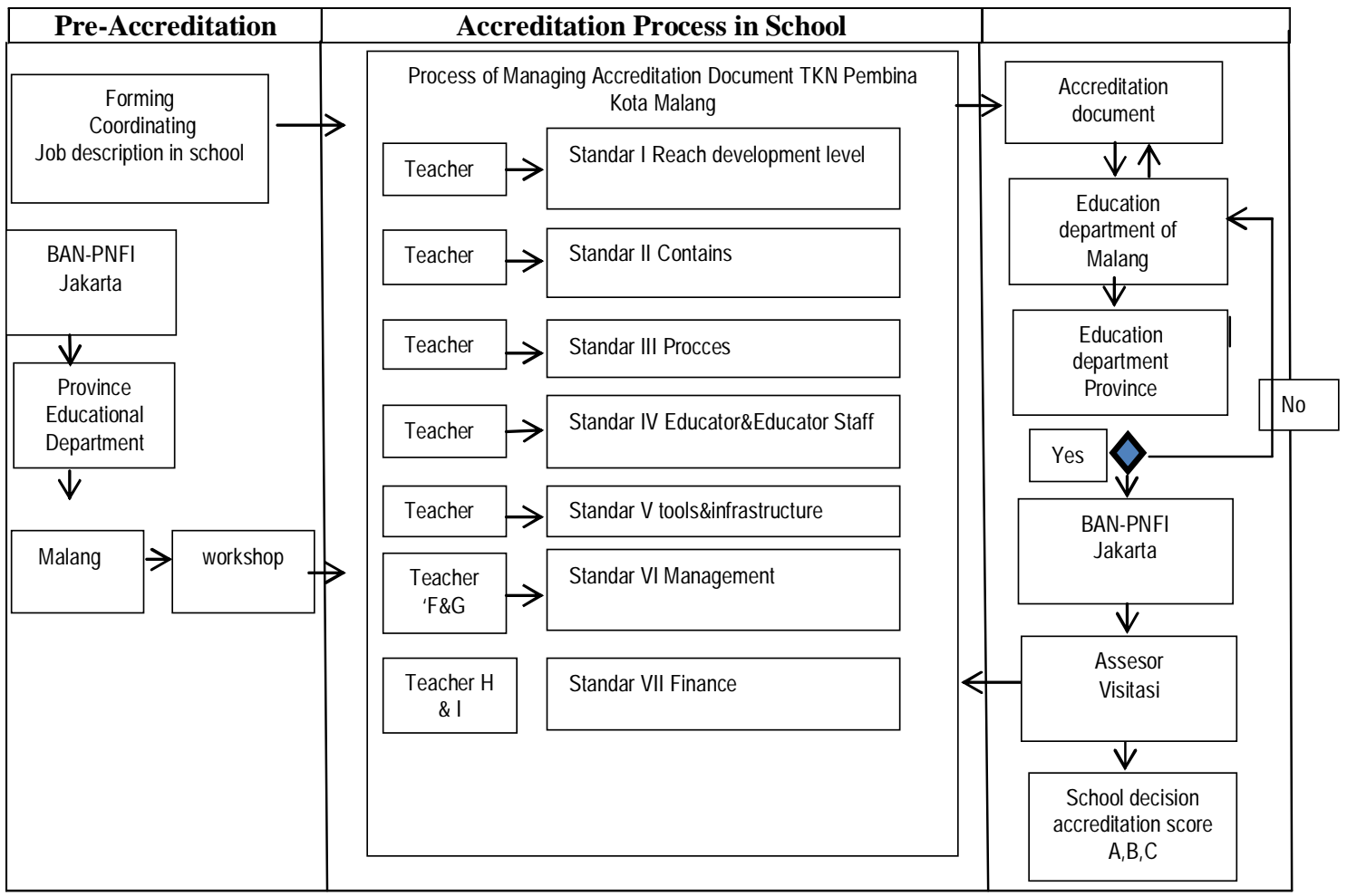

Picture 1 Quality Assurance Model of TKN I Pembina Kota Malang

Since the beginning of existence, this school has produced many student's output. But due to the building of new kindergartens which have Islamic background, the students from Berita Hidup kindergarten decreased. The amount of this school just 25 students. It consists of TK A 13 children (4 male and 9 female students), TK B 12 children ( 8 male and 16 female students). For Islamic background is 24 students (8 male and16 female students), while from christiany just 1 female student. Educational staffs of this school are just 3 people. One as headmaster and 2 as a teachers. The headmaster has just taken course of PG PAUD for 1 year. While one of the teacher is from PGSD graduate who also teaches in the kindergarten, and also the other graduated in 2016 from PGTK (double degree). The reason why parents choose TK Berita Hidup because it has good experience, patient teachers and much assistance.

By that condition, TK Berita Hidup has ever proposed for accreditation and got $\mathrm{C}$. They will submit it again on 2017 and hope to get $\mathrm{A}$, but because of that condition the headmaster is just optimistic to get B. Because of the disadvantaguous environment, too fewer students, the teachers have not graduated from S1 PG PAUD yet, lack of facilities and infrastructures, and still merge with SD. The teachers in this school have followed training on accreditation. TK Berita Hidup has done administration that is helped by 2 teachers and TU staff. They are ready to do together between the headmaster, teachers, and TU staff such as do accreditation last year. But they do not make it seriously because it is still far to conduct (in 2017). For doing school accreditation they will discuss with other teachers and will devide into 8 standards. Implementation of quality assurance model of TK Berita Hidup can be seen on Picture 2.

The last subject is TK Assalam Arjosari which has Islamic background. This kindergarten which has existed since 2010 has a vision as follows "It creates good human being who has good character, intelligent, creative, innovative, discipline, and autonomous." The school is located at Masjid Assalam complex Jl. Teluk Pelabuhan Ratu Arjosari Blimbing Malang and has 3 floors. The first floor is used toTK A (Nol Kecil), second floor is used to TK B (Nol Besar), and the third floor is used to kejar Paket program. This kindergarten is led by Mrs. Mudrikah. She has background of Elementary School pension. She does not come to her office everyday because she has to give guidance to her teachers there. She just come on Friday. If there is a problem tha can not be solved, the teacher can send message or call or come to her house and also consult in the mosque. This school has 12 human resources that consist of: 1 Headmastress, 9 teachers, 1 staff, 1 cleaning service. For the teacher, mostly graduated from S1 degree, and also who take the second S1 that is PAUD. To be a teacher in this school, the candidate has joined some tests. The requirement is not only 
formal but also informal. By giving report to the foundation that school minus of the teacher then thefoundation will take for it. After that, the participant submits letter of application, join test, interview, and training for 3 months. Then, they improve their teacher professionally with training, workshop, and seminar. The activity is urgent to all teachers so they must follow that activity. But, for administration manner, it will send TU staff. And for about an important thing it will give schedule and offer to all teachers.

Realization of Implementation Quality Model at TK Berita Hidup Supiturang Malang

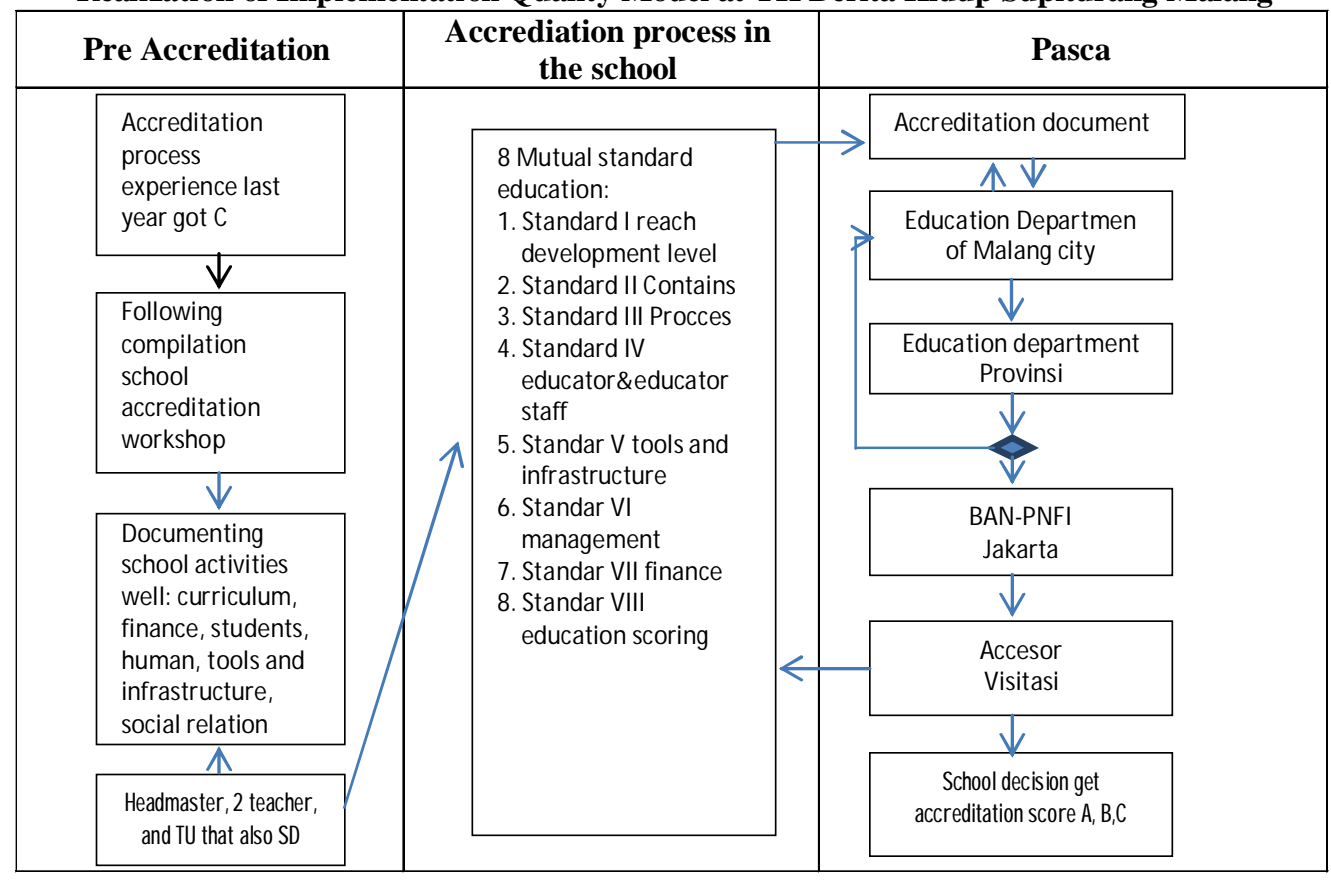

Picture 2 Implementation of Quality Assurance Model at TK Berita Hidup

Fee at TK Assalamis not too much, but the teacher is motivated that educating and teaching is one of belief to Allah. So, most teacher here teach and educate sincerely. They do not insist for higher salary. Because of the fact as a private school, the financial aspect is mostly got from student, though it is also helped by Education Department Malang. For management process, the financial sector is noted and given to foundation. The foundation gives report to branch, and branch to main branch office. If school submits a financial for activity they must make proposal that submit to foundation. And foundation will decide how much it will be given. The number of students increases every year. There are some techniques used by this school in promoting school, such as using banner, leaflet, religious activity (pengajian), etc. Parents have to register first on January and March. After that there is test about preparing student candidate for studying at Kindergarten. They are psikological specialist, doctor, and teachers who selected because there are so many student candidates. There are many kinds of reasons why parents asked their children to study at TK Asalam Arjosari, such as: near with their home, school has good care, good management, good schedule, good tools and infrastructure, professional teacher because graduated from UM, although it is too expensive but it is no problem for parents.

Learning process from Education Departmen of Malang City motivates school to teach reading, writing, and accounting (Calistung) to their students, and this is also appropriate with demand of society and elementary school (SD), after graduating from this school, the students have to able to read and write. School tries to teach student about fun learning. If the students are old enough and ready to study at elementary school that students pass. But if not, school tries to communicate with their parents. There are manystudents activities such as: Pondok Romadhon, Visit to Lanud Abd. Saleh Malang, Museum Brawijaya, Kantor Pos Besar Kota Malang, PPPGT/VEDC Office Malang, planting, eating learning, following competition, cooking class, swimming learning, radio broadcast, Outbound ke PSLK Univ. Muhammadiyah Malang, commemoration of independence day, commemoration of Kartini day, dan extrication TK B and art performance.

School must firstly plan any tools and infrastructures needed. Then it must submit to foundation. Sometimes from the foundation will handle by themselves, and also give financial to the school for supplying the needs based on situation and condition. Although this kindergarten has been built since 2010, it has not implemented accreditation yet. In implementing and joining accreditation, there are 8 standards. According to Mrs. Yani it is needed to distribute the duty that is suitable with their capability. And it needs for classroom preparation such as Rencana Pelaksnaan Pembelajaran Harian (RPPH), Rencana Pelaksnaan ePembelajaran Mingguan (RPPM), semester program, and school program in 1 year. TK Assalam Arjosari should submit for 
accreditation because it will enter the fifth year of its implementation. Before submitting document for accreditation, school must prepare administration document orderly for teachers and staff officers by conducting 6 management substances that are: curriculum, Human Resources (SDM), finance, Students, and public relation (humas). On the other hand, school has to find information to Education Department of Malang City to ask what the requirements for accreditation are. School manages all the documents and complete it if missed. Repair the school profil and strategy plan school. And alsothe headmaster as accreditation coordinator constribute theduty for teacher and staff officeas who is responsible for 8 standard. There is 1 teacher handled 1 sandard, there are 2 person handled 1 standard (for standard that have many requirements). Mutual Implementation Model TK Assalaam Arjosari can be seen on Picture 3.

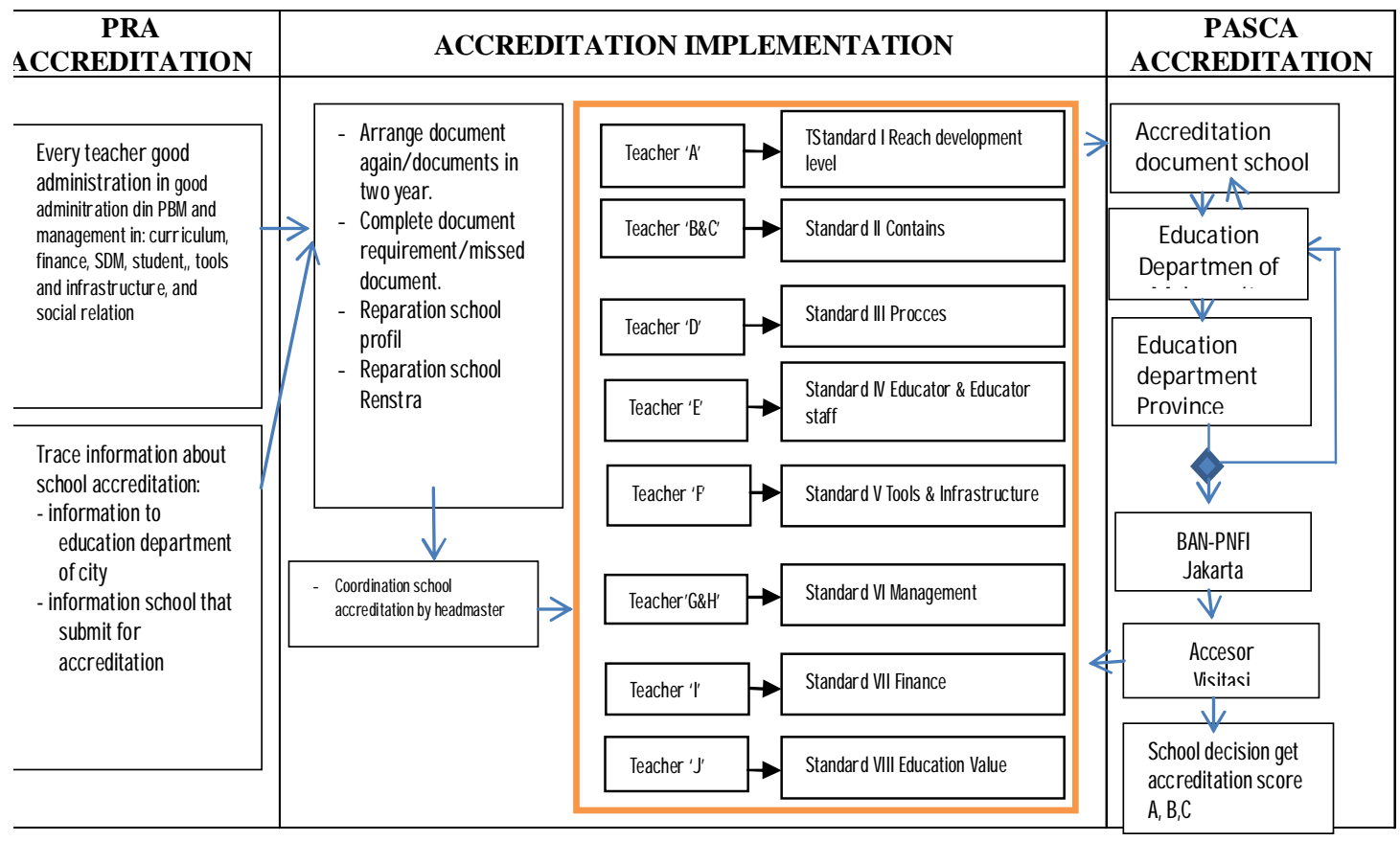

Picture 3 Mutual Implementation Model TK Assalaam Arjosari

While ideal channel model of internal quality implementation at kindergarten can be seen on Picture 4. According to the founding, this research is from third school students that has not focused on specific organization yet but focused on internal such as lnternal quality implementation formally in senior high scholl (SMA/ an equal and also university), but all of them have done quality assurance implementation activities in each school (Sunarni, 2015). For school that has established and have enough human resources (SDM), they give task to be finished in each standard. For standards that need collecting too much data is handled by more than 1 person, and for document that is not to much for collecting data, it is just handled by one person. For unestablished school and does not have enough SDM, there is no distribution duty but do together between the headmaster and teachers. If in the school there is contribute duty one of them as coordinator one of standard accreditation, this will make easy and quick to finish document report of accreditation.

If there is no distribution task and lack of SDM, they will have difficulties and obstacles for the headmaster and teachers. They will face big burden because the high duty and have to teach and also others. Although according to Robbins (1998) and
Bartol, at all (2002) organization is in relation systematically between two persons or more, they still have one purpose to reach (goods or service roduct). Herbert G. Hicks (Winardi:2003) said that some kinds of reason why the person should prepare organization are: a) social reasons to fulfill requirement, b) material reasons to increase skill, c) economical time, and d) beneficial knowledge from previous generation. From organization life cycle, Joiner in Winardi: 2003 said that the organization on the first level have some characteristic such as: (1) private relation, (2) face to face communication, (3) flexsible, (4) need private support, (5) achievement climate, and rough organization. It includes unestablished organization. For established organization, it has characteristics as follows: (1) organization structur clearly, (2) higher degree structure, and (3) appear the spesialit or expert staff.

Reimer and Gorton (at all, 2011) said that school is an institution that asks present group according to age and rooms that is lead by a teacher to study about curriculum that have level, school as institution education. School is one of organization systems where there is a number of some people that cooperate to reach school purposes that has been known as instructional purpose. In the kindergarten 
that have been established to run wheet organization have the headmaster, 2 class teacher, religion teacher, art teacher (extracurricular teacher), staff office, cleaning service, and security. From all of them have each duties that theorifice is school purposes. While for unestablished kindergarten just consist of the headmaster and some teacher. There is no contribution duty clearly, they fill each others to do their duty. Sometimes join eith others. In organization need management fungsional such as planning, organizing, leading, and controlling.

Ideal Model of Internal Quality Implementation at Kindergarten

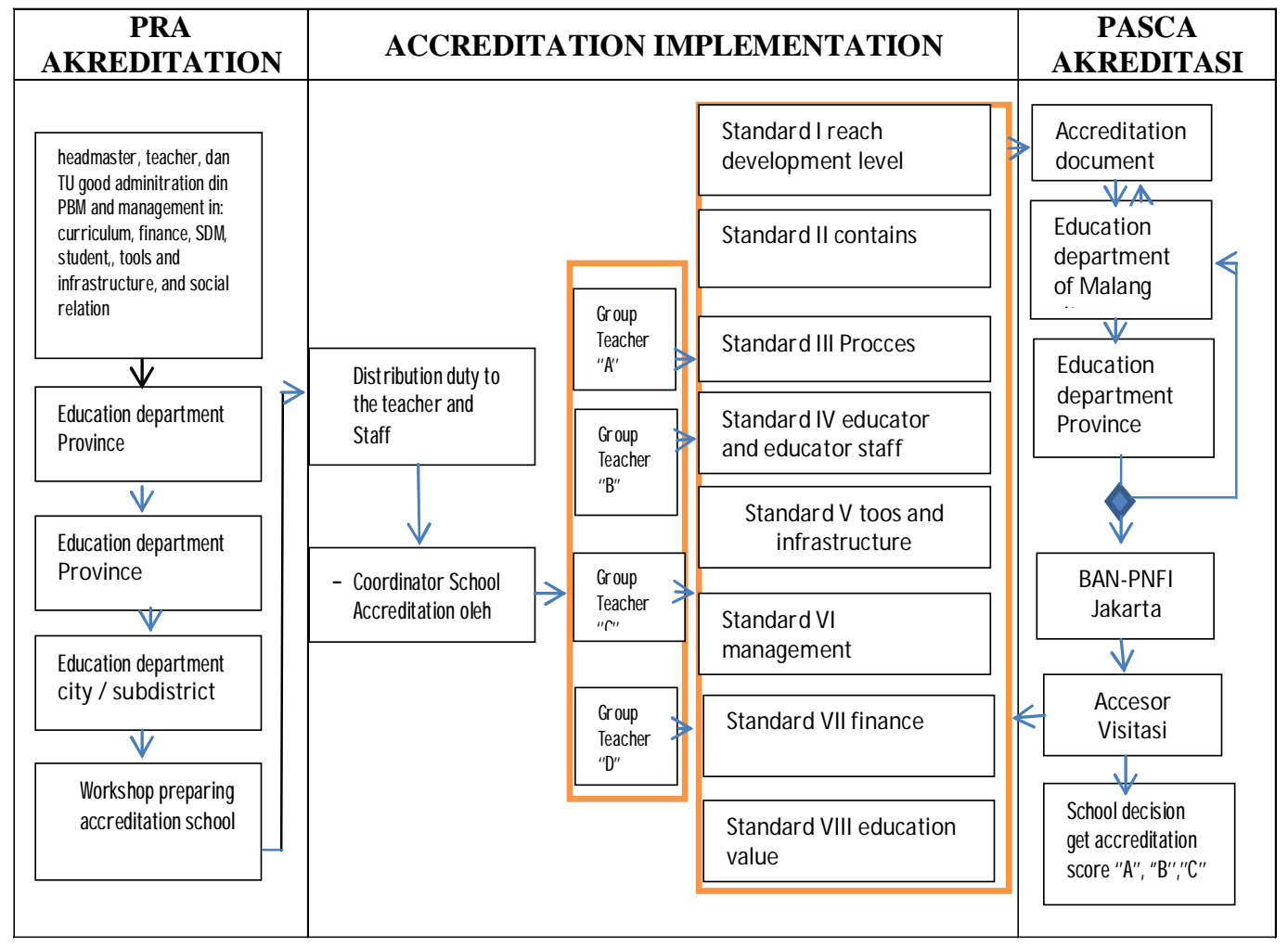

Picture 4 Ideal Channel Model of Internal Quality Implementation at Kindergarten

In a school there are organizational values that are held by citizen school as the base and identity of organization. It will be different between each others. From that orientation it is used by school to do behavior and solving problem. According to Cathy (in Sobirin, 2007) organization value specifically is conviction from personal or group about action that is made base or identity to do activity, consider organization urpose, or choose fitting do some alternative. In a organization which functions as a base and guide for new member, there are good behavior and solving problem, so it can be different from one organization with others.

Alport in Robbins (1996) devided value types into 6 (six), they are: theoretical, economic, aesthetic, social, political, and religious aspects. Although this kindergarten used as subject of research does not have specific organization about internal quality implementation, all schools actually have done school management according to each school capacity. School have planning, organization, and evaluation to management substance such as curriculum, finance, tools and infrastructure, students, human resources (SDM), and society relation. According to Bartol, et all (2002), Massie (1964), and Kurniadin and Machali (2012) management iscooperation process between groups to reach organization purposes by means of functions that are planning, organization, and control.

Educations in Indoenesia especially in the Java have quantity problem can be said is finished, and direct to quality problem. From the quality education in the Java Island becomes barometer but is compared with other countries stiil far from desire. Government stiil need to work hard to make equal education with globalization. It has great challenge, itneed to new founding in increase nation quality, one of them do Total Quality Managemen (TQM). Santosa (in Tjiptono, 2001) said TQM management system that raise quality as effort strategy that oriented on consument satisfaction that involvedall the member of organization.

Pandi (2000) said for success implementation TQM the organization should stand on 8 element keys TQM, that are: (1) ethics; (2) integrity; (3) trust; (4) training; (5) teamwork; (6) leadership; (7) recognation; and (8) communication. Sonhadji (2012:195) said "basically mutual implementation is government policy as an effort for organization arrangement in order to have goodquality. Education need value standaritation while the means of quality standard is combination characteristic of service and goods, include of 
management system that relative established and suitable with demand consument.

Salis (in Komariah, 2005) said that standard quality can be seen by two side that are: a) product standard or service are showed by: (1) suitable with conformance to specification, (2) fitness for purpose or us, (3) zerodefect, (4) right fist time, every time; (b) customer standard are showed by: (1) customer satisfaction if product and services exceeding customer expectation, (2) delighting the customer, sostandard quality on education organizing can be attention of product and servicesand how the customer get the satisfaction. Basicallly quality implementation is very needed in education side.

The improvement of quality isvery important for institution or organization that use good control from theirselves. Because school as important organization need to know what the consument wants, customer satisfaction give much influence for social belief to attend school their children on benefit school. Internal quality implementation is done as a policy institution. Institution or school able to decided their sitematic quality in order to care for their sistym or procedure by size and standard that heve been decided by theirselves.

Quality Assurance System (QAS) is unit education from educator staff standard which reference from national standard, mutual standard and service standard (that include of input, process, procedur, and outcome). In the Kindergarten that do external audit managemen do by BAN-PNF, that have duty for handled accreditation Play Group (KB), Kindergarten, and early childhood education programs. While internal audit managemen isinternal quality implementation as the purpose to control and audit internal mutual school.

This is an internal school policy. Although in thesubject of the research doesn't found formally there is mutual implementation organizationbut have been done managemen fungsional and activities internal mutual implementation and have school administration correctly.

\section{CONCLUSION AND SUGGESTION Conclusion}

The conclusion of this research are: (1) quality model implementation in 3 kindergarten school as subject research, there is very established school, established, and not established yet; (2) all subjects of this research have been organized well on contributing task for prepare implementation quality external documents for established school and have enough human resources but also there is no contributing task and do together for not established school yet and have not or not enough human resources; (3) all of them does not organization that especially for handle quality internal implementation buthave already do activities implementational internal quality and have orderschool administration; and (4) function of Education Official of City, the leader of institute and headmaster have guide, motivate, and direct quality internal and external school implementation (acrreditade school).

\section{Suggestion}

The researcher give suggestions for: (1) the leader of Education Official of City to prepare external quality implementation have tried to give workshop or training about submission of school acreditation. But, it is better to give instruction for the school to always order admistration and the most important is to do internal quality implementation well. Education Official of City has criteria of implementation quality standard which has been obedient by each kindergarten in Malang city area, (2) headmaster, ought to give otivation, guiding and briefing for the teacher and officer to always do standard quality well for prepare quality eksternal implementation which is handeled by BAN-PNF, (3) subdivission of quality implementation institute, although there is no special organization that handled implementation not only internal or external, but need teacher or staff officer who given task on formal or informal to control internal quality so that make easy the institute for prepare school acreditation, (4) student's parents should choose school for their childrens attention about quality school and follow to share increase school quality especially in the kindergarten. 5) Other researchers, need other approach in this research such as qualitative and improvement to quality implementation not only internal but also external.

\section{REFERENCES}

[1] Bartol, K; Martin, D; Tein, M; \& Matthews, G. 2002 Management: a Pacific Rim Focus, $3^{\text {rd }}$ Edition. New York: McGraw-Hill Companies, Inc.

[2] Gutama dan Herarti, F. 2015. Studies of Improvement Mutual implementation system PAUD, FebruaryMarch 2015. Retrieved December 2, 2016, from www.academia.edu.

[3] Kamariah, A. and Triatna, C. 2005.Vesionary Leadership, Going to effective school Jakarta: Bumi Aksara.

[4] Kurniadin, D., and Machali, I. 2012. Education Management: Concept \& Prinsip Education Management. Bandung: Ar-Ruzz Media.

[5] Massie, J. H. 1964. Essentials of Management. London: Prentice-Hall, Inc.

[6] Miles, M. B., and Huberman, A.M. 1992. Quaitative Data Analysis. Translation Tjetjep Rohendi Rohidi. Jakarta: UI Press.

[7] Pandhi, N. The Eight Element of TQM. Retrieved December 2, 2016, from http://www.isixsigma.com/library/content/c021230a.as p.

[8] Education Minister Education National Regulation Nomor 63 year 2009 about Mutual Implementation Education System. Retrieved December 2, 2016, from http://www.pojokdikpora.com).

[9] Education Minister Education National Regulation Nomor 58 year 2009 about Education child School Standard. Retrieved December 2, 2016, from http://www.pojokdikpora.com).

[10] Robbins, S. P. 1998. Organizational Behavior. New Jersey: Pearson Education, Inc.

[11] Robbins. 1996. Organization: Concepts-Application. Indonesia Edition, Jilid 1. Translator Hadyana Pujaatmaka. Jakarta: Prenhallindo.

[12] Sagala, S. 2011. Strategy Management in Mutual Education Improvement. Bandung: Alfabeta. 
[13] Sobirin, A. 2007. Organization Culture, Explanation, Meanings and Application in Organization Life. Yogyakarta: YPKN.

[14] Sonhadji, A. 2012. Human, Technology, and Education to New Civilization. Malang: State University of Malang.

[15] Sunarni. 2015. Audit Implementation Model Management Internal as Control Organization at SMKN Malang City. Malang: Faculty of Education, State University of Malang.

[16] Wahyuni, S. 2015. Strategy Value Improvement Service pre School: Studies of Multisitus on three institution PAUD at Malang City. Disertation. Malang: State University of Malang.

[17] Winardi, J. 2003. Organization Theory and Organizational. Jakarta: RajaGrafindo Persada. 